\title{
Performance verification of methodology for determination of nitrate ion in drinking water samples
}

\author{
Verificação de desempenho de metodologia para determinação de íon nitrato em \\ amostras de água potável
}

\author{
Beatriz Galdino Ribeiro1, Paulo Roberto de Barros Salomão David², Tatiana Pinto Pereira Daltro², \\ Lívia Vieira Carlini Charamba ${ }^{3}$, Marcelo Farias de Andrade², Daniella Carla Napoleão ${ }^{3}$ \\ ${ }^{1}$ Departamento de Antibióticos, Universidade Federal de Pernambuco, PE, Brasil \\ beatrizgaldinoribeiro@gmail.com \\ ${ }^{2}$ Laboratório Nacional Agropecuário, Ministério da Agricultura, PE, Brasil \\ paulo.david@agricultura.gov.br; tatiana.daltro@hotmail.com; marcelo.farias@agricultura.gov.br \\ ${ }^{31}$ Departamento de Engenharia Química, Universidade Federal de Pernambuco, PE, Brasil \\ liviacharamba@gmail.com; danicarlan@gmail.com
}

\begin{abstract}
Contaminated water is one of the main public health risks. One way to assess its quality is by quantifying nitrate through ultraviolet (UV) spectrophotometry. In this work, the performance of the UV spectrophotometric method for nitrate ion determination in water was studied, with linearity, precision, accuracy, limit of detection (LOD), limit of quantification (LOQ) and robustness being verified. In the working range studied (5.0-25.0 $\left.\mathrm{mgN} \cdot \mathrm{L}^{-1}\right)$, all validation parameters are in accordance with the acceptance criteria established by INMETRO. In linearity, the value of $r(0.999)$ was higher than the criterion (0.995). In the study of precision and accuracy, the coefficients of variation for repeatability and intra-laboratory reproducibility were 1.79 and $2.34 \%$, and 1.44 and $2.52 \%$, respectively $(<5 \%)$. The value of the relative error (15.8 and $8.1 \%$ ) was also lower than the criterion ( $\leq 20 \%$ ). The LOD and LOQ obtained were 0.56 and $1.70 \mathrm{mgN} \cdot \mathrm{L}^{-1}$, respectively. In the evaluation of the robustness no factor had a significant effect on the final result. Analyzing real samples, the percentages of recovery were between 88.5 and $103.6 \%$, according to the established criteria (80-110\%). In this way, it can be said that the method presents reliability to the intended purpose.
\end{abstract}

Keywords: Water analysis; Nitrate; Performance verification

\section{Resumo}

Águas contaminadas representam um dos principais riscos à saúde pública. Uma forma de avaliar sua qualidade é pela quantificação de nitrato via espectrofotometria de ultravioleta (UV). Neste trabalho foi realizada a verificação de desempenho do método espectrofotométrico de UV para determinação de íon nitrato em água, estudando-se a linearidade, precisão, exatidão, limite de detecção (LOD), limite de quantificação (LOQ) e robustez. Na faixa de trabalho estudada (5.0-25.0 $\left.\mathrm{mgN} \cdot \mathrm{L}^{-1}\right)$, todos os parâmetros de validação estão em concordância com os critérios de aceitação estabelecidos pelo INMETRO. Na linearidade, o valor de $r(0,999)$ apresentou-se maior que o critério (0.995). No estudo da precisão e exatidão, os coeficientes de variação para a repetitividade e reprodutibilidade intralaboratorial foram de 1.79 e $2.34 \%$, e 1.44 e $2.52 \%$, respectivamente $(<5 \%)$. O valor do erro relativo ( 15.8 e $8.1 \%$ ) também foi inferior ao critério ( $\leq 20 \%)$. O LOD e LOQ obtidos foram de 0.56 e $1.70 \mathrm{mgN} \cdot \mathrm{L}^{-1}$, respectivamente. Na avaliação da robustez nenhum fator apresentou efeito significativo no resultado final. Analisando-se amostras reais, os percentuais de recuperação ficaram entre 88.5 e $103.6 \%$ atendendo ao critério estabelecido (80-110 \%). Desse modo, podese afirmar que o método apresenta confiabilidade à finalidade pretendida.

Palavras-chave: Análise de água; Nitrato; Verificação de desempenho 


\section{INTRODUCTION}

Water is considered the most important natural resource, because it has fundamental importance for the existence of life on the planet. Therefore, it is essential to search for quality control with the objective of minimizing the transmission of diseases that may compromise the health of the population (Mendelezia et al., 2017). In order to monitor water quality, it is necessary to determine the concentration of some chemical components, whose limits are legislated, through the use of specific and reliable laboratory methods (LIMA et al., 2015, BUI et al., 2016).

Regarding the quality of water for human consumption, one way of verifying its quality is by quantifying the nitrite and nitrate ions, whose limiting concentrations as a standard of potability are, respectively, $1 \mathrm{mgN} \cdot \mathrm{L}^{-1}$ and $10 \mathrm{mgN} \cdot \mathrm{L}^{-1}$ (BRAZIL, 2011b). The nitrate ion, which comes from the process of nitrification of ammonia by the bacteria present in water, when consumed by humans can cause the formation of nitrosamines, potentially carcinogenic, from the natural transformation into nitrite ion in the body and subsequent reaction with amine molecules, as well as the replacement of hemoglobin oxygen by nitrite, causing methemoglobinemia, which prevents the transport of oxygen from the alveoli to the tissues, with a risk of death for the individual (KREUTZ et al., 2012; MOO et al., 2016).

In this context, it is very important to control the water used for human consumption in order to ensure that the presence of these ions meets drinking standards. For this, it is necessary to use analytical technique with good sensitivity, low cost and easy handling, as is the case of ultraviolet/ visible (UV/ is) spectrophotometry (BEKA; UDOM, 2014). Among the spectrophotometric methods used for this purpose, the standard method described by the American Public Health Association (APHA) is applicable in waters with low organic matter content; and is based on the measurement of nitrate absorption in the ultraviolet region at $220 \mathrm{~nm}$ using 1 mol. $\mathrm{L}^{-1}$ hydrochloric acid $(\mathrm{HCl})$ to eliminate interferents. Because the organic matter influences the absorbance reading by also absorbing radiation at $220 \mathrm{~nm}$, a second absorbance measurement at $275 \mathrm{~nm}$ is performed to correct the reading value corresponding to the nitrate since it does not absorb at a wavelength of $275 \mathrm{~nm}$ (APHA, 2012, GUIMARÃES, DURÃO, AZENHA, 2014).

According to INMETRO (2011), for a laboratory to use chemical test methods issued by standardization bodies and recognized organizations in its area of operation, it is necessary to demonstrate adequate operating conditions that meet specific conditions existing in its facilities before implementing them. For this, the method validation process is of great importance, since it confers reliability and consistency to the quantitative results obtained (NAZ et al., 2014; SILVA et al., 2014). Therefore, some characteristics or performance parameters must be determined: selectivity and specificity (description of the measurand), measurement range or linearity range, calibration and traceability, trend, linearity, limit of detection (LOD), limit of quantification (LOQ), robustness and precision (ZENEBON; PASCUET; TIGLEA, 2008; KHAN et al., 2017).

Several validation studies for different analytical methodologies have already been performed. Khan et al. (2017) developed and validated an analytical method for the determination of rifampicin in a mixture of isoniazid and pyrazinamide by ultraviolet spectrophotometry, obtaining good linearity $\left(\mathrm{R}^{2}\right.$ $=0.990)$ in the concentration range studied $\left(2.5-35.0 \mu \mathrm{g} \cdot \mathrm{mL}^{-1}\right)$ with coefficient of variation $(\mathrm{CV})$ in the study of precision varying from 1.09 to $2.99 \%$ and a percentage recovery from $96.7 \pm 0.9$ to $101.1 \pm 0.4$. Similar results were found in the studies of Sen et al. (2016) and Jain and Pethkar (2016), who carried out validation of spectrophotometry methodology in the ultraviolet region. According to the first authors, the method of simultaneous determination of teneligliptin bromidate and metformin hydrochloride was developed and validated, in which correlation coefficients between 0.9984 and 0.9996 were obtained for the linearity range of 1 to $20 \mu \mathrm{g} . \mathrm{mL}-1 \mathrm{CV}$ between 0.38 and $1.16 \%$ and recovery percentage ranging from $98.14 \pm 0.81$ to $101.01 \pm 0.38$. According to the second group of authors, the validation of the method for the analysis of nortriptyline hydrochloride in bulk and tablet dosage forms obtained, in the linearity study, a correlation coefficient of $0.9998\left(5-25 \mu \mathrm{g} \cdot \mathrm{mL}^{-1}\right), \mathrm{CV}$ ranging from 0.081 to $0.696 \%$ (accuracy), and recovery percentage between 98.10 and 99.41 . Thus, the three studies cited have been able to employ an efficient method for the detection of different analytes in the ultraviolet 
region by using the spectrophotometric technique.

Thus, this work had the objective of evaluating the performance of the nitrate ion determination method using spectrophotometry in the ultraviolet region to verify the water potability. For this purpose, the INMETRO required validation parameters: linearity, precision, accuracy, robustness, limit of quantification (LOQ) and limit of detection (LOD) and quantification of nitrate content in different aquatic matrices.

\section{MATERIAL AND METHODS}

\subsection{Implementation of the standard APHA methodology for determination of nitrate ion}

The performance verification, as recommended by INMETRO (2011), was carried out using a previously standardized methodology and used for determination of nitrate ion by APHA (2012). Absorbance readings were performed on a UV/VIS spectrophotometer (GE Healtcare) at wavelengths of 220 and $275 \mathrm{~nm}$.

According to APHA (2012), an empirical correction of absorbance is required by subtracting twice the absorbance value obtained at $275 \mathrm{~nm}$ from the absorbance value obtained at $220 \mathrm{~nm}$ (Equation 1).

Corrected absorbance $=\mathrm{ABS}_{220}-\left(2 \times \mathrm{ABS}_{275}\right)$

\subsection{Preparation of stock solution and verification of methodology performance}

A stock solution of the standard potassium nitrate reagent $\left(\mathrm{KNO}_{3}\right.$ - supplied by NIST), with concentration equal to $1000 \mathrm{mgN} \cdot \mathrm{L}^{-1}$, was prepared in continuity with the nitrate determination process. This solution was preserved with chloroform $\left(\mathrm{CHCl}_{3}\right)(0.2 \mathrm{~mL} \mathrm{CHCl} 3 / 100 \mathrm{~mL}$ solution). From the stock solution, intermediate solutions with a concentration of $200 \mathrm{mgN} \cdot \mathrm{L}^{-1}$ were also prepared, which were used in the tests for linearity, precision and accuracy.

Linearity analysis was performed based on the construction of the analytical curve with 5 concentrations, with 5 replicates each and determination of the correlation coefficient ( $r$ ). For the precision test, two levels were evaluated (repeatability and intra-laboratory reproducibility), and replicates of the intermediate solution were prepared independently, with concentrations equal to 5.0 $\mathrm{mgN} \cdot \mathrm{L}^{-1}$ and $10.0 \mathrm{mgN} \cdot \mathrm{L}^{-1}$. The accuracy was determined based on the coefficient of variation $(\mathrm{CV})$, according to Equation 2. These two concentrations were used to evaluate the accuracy, which was determined based on the calculation of the relative error (Equation 3) (INMETRO, 2011).

$$
\mathrm{CV}(\%)=(\mathrm{s} / \mathrm{x}) \cdot 100
$$

$$
\operatorname{RE}(\%)=[(\mathrm{xLAB}-\mathrm{xv}) / \mathrm{x}] \cdot 100
$$

In which $\mathrm{x}=$ arithmetic mean of the number of measurements, $\mathrm{s}=$ absolute standard deviation estimate value, $\mathrm{X}_{\mathrm{LAB}}=$ experimental value or arithmetic mean of values obtained and $\mathrm{XV}=$ value accepted as true.

In order to determine the robustness of the method, a fractional factorial planning of three resolution variables (25-2) was performed (BARROS NETO; SCARMINIO; BRUNS, 2010; BRASIL, 2011a), in which two stock solutions were prepared using two distinct reagents: $\mathrm{KNO}_{3}$ (NIST) and $\mathrm{NaNO}_{3}$ (Merck). These solutions were preserved with $\mathrm{CHCl}_{3}$, and 8 assays were performed, in which 4 used $\mathrm{KNO}_{3}$ as reagent (assays 1 to 4 ) and 4 employed $\mathrm{NaNO}_{3}$ (assays 5 to 8 ). The solutions were prepared for the concentration level of $10 \mathrm{mgN} \cdot \mathrm{L}^{-1}$, corresponding to the maximum allowed value for drinking water by Ordinance No. 2914 (BRASIL, 2011b). The factors defined for the study are described in Table 1. 
Table 1- Factors and matrix of coefficients of contrasts for the study of method robustness

\begin{tabular}{c|c|c|c|c|c}
\hline Fator & $\mathbf{A}$ & $\mathbf{B}$ & $\mathbf{C}$ & $\mathbf{D}$ & E \\
\hline \multirow{2}{*}{ Ensaio } & Salt & $\begin{array}{c}\text { Volume } \\
\mathrm{HCl}(\mathrm{mL})\end{array}$ & $\begin{array}{c}\text { Concentration } \\
\mathrm{HCl}\left(\mathrm{mol} \cdot \mathrm{L}^{-1}\right)\end{array}$ & Brand HCl & Temperature $\left({ }^{\circ} \mathrm{C}\right)$ \\
\cline { 2 - 6 } & $\mathbf{5}$ & $\mathbf{5}$ & \multicolumn{2}{|c}{$\mathbf{X}_{\mathbf{i}}$} \\
\hline $\mathbf{1}$ & $1(\mathrm{~N})$ & $1(1.0)$ & $\mathbf{C}$ & $\mathbf{D}$ & $\mathbf{E}$ \\
\hline $\mathbf{2}$ & $1(\mathrm{~N})$ & $1(1.0)$ & $-1(0.25)$ & $-1(\mathrm{~V})$ & $-1(30)$ \\
\hline $\mathbf{3}$ & $1(\mathrm{~N})$ & $-1(0.5)$ & $1(0.5)$ & $1(\mathrm{M})$ & $-1(30)$ \\
\hline $\mathbf{4}$ & $1(\mathrm{~N})$ & $-1(0.5)$ & $-1(0.25)$ & $-1(\mathrm{~V})$ & $1(15-25)$ \\
\hline $\mathbf{5}$ & $-1(\mathrm{M})$ & $1(1.0)$ & $1(0.5)$ & $-1(\mathrm{~V})$ & $1(15-25)$ \\
\hline $\mathbf{6}$ & $-1(\mathrm{M})$ & $1(1.0)$ & $-1(0.25)$ & $1(\mathrm{M})$ & $-1(30)$ \\
\hline $\mathbf{7}$ & $-1(\mathrm{M})$ & $-1(0.5)$ & $1(0.5)$ & $-1(\mathrm{~V})$ & $-1(30)$ \\
\hline $\mathbf{8}$ & $-1(\mathrm{M})$ & $-1(0.5)$ & $-1(0.25)$ & $1(\mathrm{M})$ & $1(15-25)$ \\
\hline
\end{tabular}

Finally, the limits of detection (LOD) and quantification (LOQ) of the method were determined. Thus, we used Equations 4 and 5, as proposed by Ribani et al. (2004).

$$
\begin{aligned}
& \mathrm{LOD}=3,3 \cdot(\mathrm{s} / \mathrm{S}) \\
& \mathrm{LOQ}=10 \cdot(\mathrm{s} / \mathrm{S})
\end{aligned}
$$

Where $\mathrm{s}=$ the standard deviation of the response (estimate of the standard deviation of the blank, the regression line equation or the linear coefficient of the equation) and $S=$ Slope or the angular coefficient of the analytic curve.

\subsection{Quantification of nitrate ion in drinking water samples}

After the study of the validation parameters to confirm the validity of the method, the analysis of six previously coded samples of drinking water was carried out to determine the level of nitrate ion recovery percentage in a real sample. For this, two solutions were prepared for each sample: the first with $9 \mathrm{~mL}$ of the sample in a $10 \mathrm{~mL}$ volumetric flask and the second with $9 \mathrm{~mL}$ of the sample and 0.5 $\mathrm{mL}$ of the intermediate solution, and the volume was measured with deionized water. The samples were read in the UV spectrophotometer and the percentage recovery determined according to Equation 6 (INMETRO, 2011).

$$
R(\%)=\left[\left(C_{1}-C_{2}\right) / C_{3}\right] \cdot 100
$$

In which $C_{1}=$ concentration determined in the added sample; $C_{2}=$ concentration determined in the sample not added and $C_{3}=$ concentration added.

\section{RESULTS AND DISCUSSION}

\subsection{Performance verification of the methodology}

Based on the readings made to evaluate the linearity of the method, a previous study of the dispersion of the results was carried out using the Grubbs test (Equations 7 and 8) (OLIVEIRA, 2008). The percentage of residues was also analyzed for each level of concentration employed (Equation 9). The results are shown in Table 2. 


$$
\begin{aligned}
& \mathrm{G}<=[(X-x \mathrm{i}<) / s] \\
& G>=[(x i>-X) / s]
\end{aligned}
$$

Residue $(\%)=\left[\left(\mathrm{y}_{\text {med }}-\mathrm{y}_{\text {calc }}\right) / \mathrm{ycal}_{\text {cal }}\right] \cdot 100$

In which: $G<$ is the Grubbs test for the lowest measured value; $G>$ is the Grubbs test for the highest measured value; $X$ is the mean value; $x i<$ is the lowest measured value; $x i>i s$ the largest measured value and $\mathrm{s}$ is the standard deviation estimate; $\mathrm{ymed}$ is the measured value and ycalc is the calculated value.

Table 2- Corrected mean absorbance, residue percent, and Grubb's (95\% confidence) values

\begin{tabular}{|c|c|c|c|c|}
\hline Concentration $\left(\mathrm{mgN} \cdot \mathrm{L}^{-1}\right)$ & ABSCOR & $\mathrm{ABS}_{\text {con }} \mathrm{MEAN} \pm \mathrm{s}$ & Residues (\%) & G TEST \\
\hline \multirow{5}{*}{5.0} & 0.049 & \multirow{5}{*}{$0.057 \pm 0.051$} & -17.469 & 0.106 \\
\hline & 0.059 & & 2.441 & 0.558 \\
\hline & 0.060 & & 4.067 & 0.625 \\
\hline & 0.060 & & 4.067 & 0.625 \\
\hline & 0.025 & & - & 1.702 \\
\hline \multirow{5}{*}{10.0} & 0.110 & \multirow{5}{*}{$0.112 \pm 0.015$} & 0.854 & 1.483 \\
\hline & 0.112 & & 0.946 & 0.135 \\
\hline & 0.112 & & 0.946 & 0.135 \\
\hline & 0.113 & & 1.823 & 0.539 \\
\hline & 0.114 & & 2.684 & 1.214 \\
\hline \multirow{5}{*}{15.0} & 0.159 & \multirow{5}{*}{$0.165 \pm 0.002$} & -3.346 & 1.109 \\
\hline & 0.161 & & -2.062 & 0.752 \\
\hline & 0.165 & & 0.412 & 0.036 \\
\hline & 0.168 & & 2.190 & 0.501 \\
\hline & 0.173 & & 5.017 & 1.396 \\
\hline \multirow{5}{*}{20.0} & 0.209 & \multirow{5}{*}{$0.214 \pm 0.006$} & -4.163 & 1.481 \\
\hline & 0.214 & & 1.729 & 0.109 \\
\hline & 0.214 & & 1.729 & 0.109 \\
\hline & 0.216 & & -0.787 & 0.439 \\
\hline & 0.219 & & 0.594 & 1.261 \\
\hline \multirow{5}{*}{25.0} & 0.266 & \multirow{5}{*}{$0.273 \pm 0.004$} & -1.909 & 1.664 \\
\hline & 0.273 & & 0.703 & 0.049 \\
\hline & 0.274 & & 1.066 & 0.294 \\
\hline & 0.274 & & 1.066 & 0.294 \\
\hline & 0.277 & & 2.137 & 1.028 \\
\hline
\end{tabular}
for the five concentration levels in the study of the linearity of the method

In relation to the percentage of residues (Table 2), it was found that the values obtained are not dispersed to $95 \%$ confidence for the Grubbs test applied, which for 5 samples should have a value lower than 1.672 (ANDRIOTTI, 2005). However, in the same table, it can be verified that in the concentration level of $5.0 \mathrm{mgN} \cdot \mathrm{L}^{-1}$, there was a corrected absorbance value equal to $0.025 \mathrm{~nm}$ considered as an outlier, since it presented $G$ value equal to 1.702 and residue percentage of $-114.88 \%$, greater than the limit specified by INMETRO for residues of $\pm 20 \%$, so that this point was eliminated (BRASIL, 2014). Therefore, after eliminating this value, we were able to construct the analytical curve (Figure 1) and the residual scatter plot (Figure 2). 
Figure 1- Analytical curve for the study of linearity

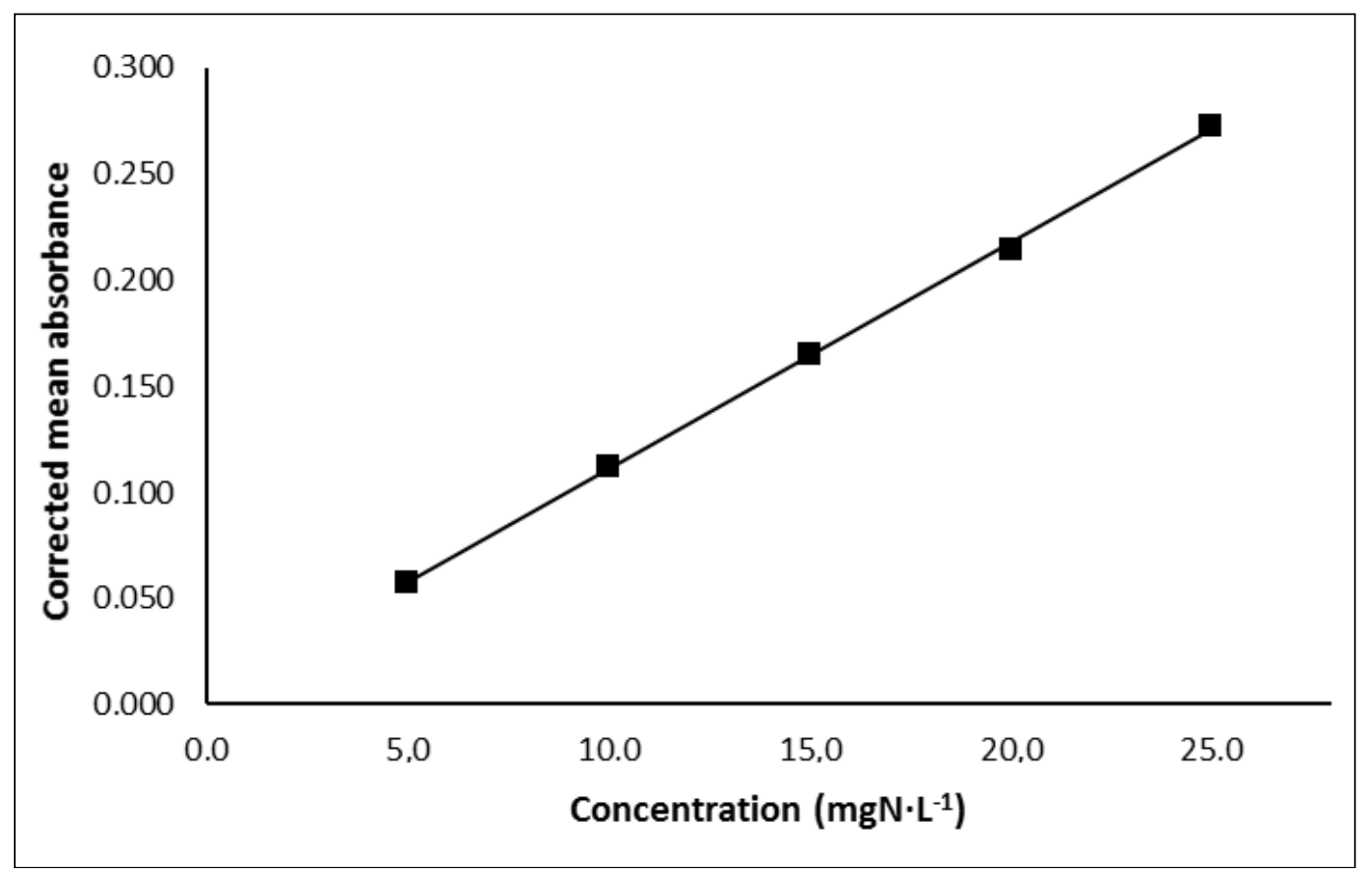

Figure 2- Scatter plot of the residues in the study of linearity

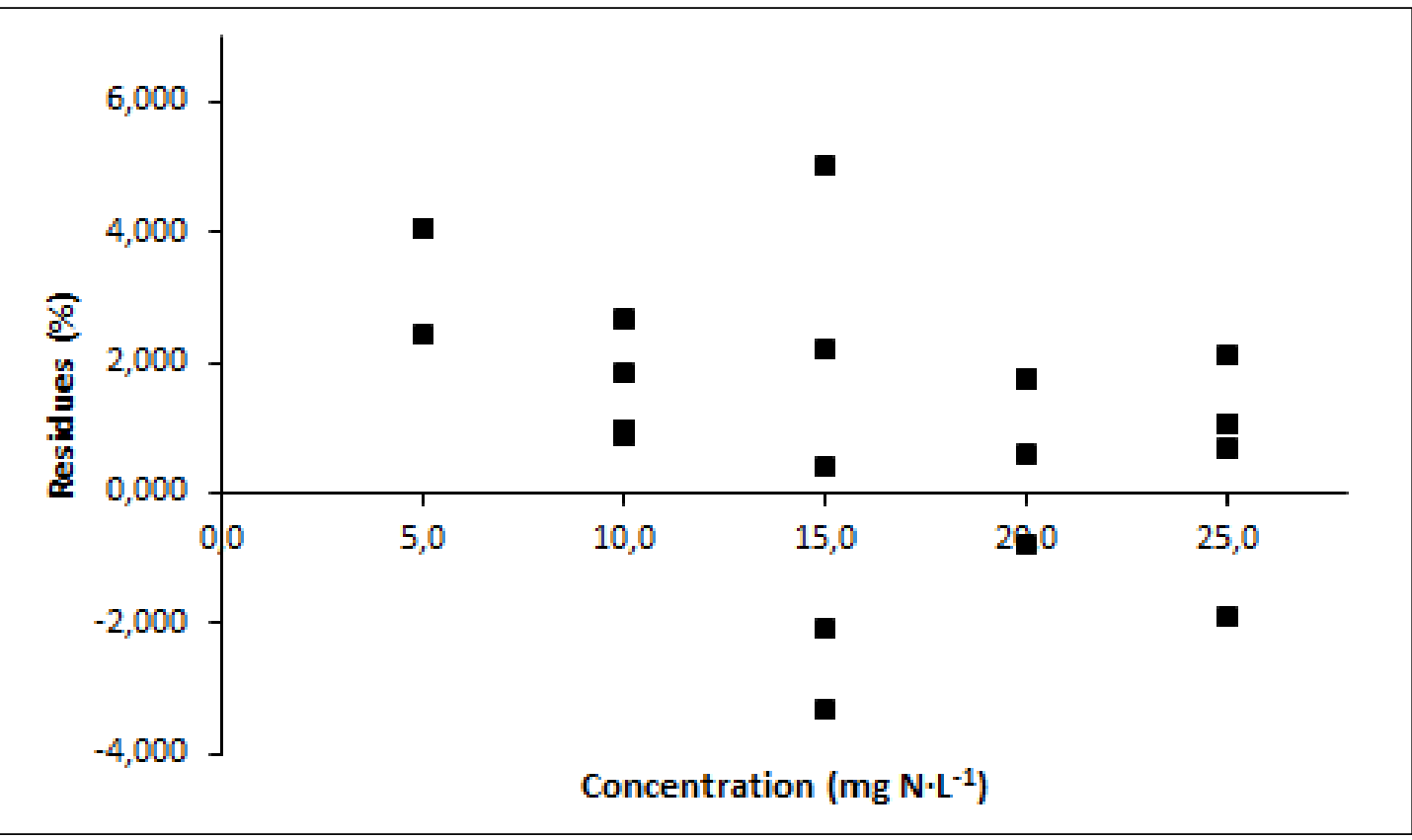


From the analytical curve, it were obtained the equation of the curve (Equation 10) and the value of the correlation coefficient ( $r$ ) (0.999) and all percentages of residues. These results are in accordance with the values specified by INMETRO (2011) and ANVISA (2003), where $r$ must present values greater than or equal to 0.995 and 0.990 , respectively. The same occurred for the results of the percentage of residues that should be less than or equal to $20 \%$, meeting the linearity requirements. Similar results were found by Guimarães, Durão and Azenha (2014), who used the same analytical methodology to determine nitrate in water (concentration range of 0.5 to $5.0 \mathrm{mgN} \cdot \mathrm{L}^{-1}$ ), where they obtained a correlation coefficient equal to 0.999 .

From the values of the CV obtained, precision analysis was performed. The results obtained are shown in Table 3. Through the analysis of this Table, it was verified that the method is accurate, since CV values (\%) were lower than 5\% (BRASIL, 2003).

$$
y=0.0107 x+0.004
$$

Table 3 - Results of the repeatability test and intra-laboratory reproducibility obtained in the study of the precision of the method

\begin{tabular}{c|c|c|c|c}
\hline \multirow{2}{*}{ Concentration level } & \multicolumn{2}{|c|}{ Repeatability } & \multicolumn{2}{c}{ Intra-laboratory reproducibility } \\
\cline { 2 - 5 } & Mean Conc. $\pm \mathbf{~ s}$ & $\mathbf{C V ~ ( \% )}$ & Mean Conc. $\pm \mathbf{s}$ & CV (\%) \\
\hline $5.0 \mathrm{mgN} \cdot \mathrm{L}^{-1}$ & $4.21 \pm 0.08$ & 1.79 & $4.20 \pm 0.06$ & 1.44 \\
\hline $10.0 \mathrm{mgN} \cdot \mathrm{L}^{-1}$ & $9.19 \pm 0.22$ & 2.34 & $9.12 \pm 0.23$ & 2.52 \\
\hline
\end{tabular}

In a more detailed analysis carried out by the Ministério da Agricultura Pecuária e Abastecimento do Brasil (MAPA) (BRASIL, 2014), it is also necessary to analyze if the values obtained from CV meet the criteria established by the equation of Horwitz (Equation 11).

$$
\operatorname{RSD}=2 \cdot(1-0.5 \cdot \log C)
$$

In which: $\mathrm{C}$ is the analyte concentration in the sample or standard (dimensionless) and RSD is the relative standard deviation.

Using the Equation 10, it can be verified that for the level of $5.0 \mathrm{mgN} \cdot \mathrm{L}^{-1}$, the value of RSD should be less than or equal to $12.56 \%$, whereas for the level of $10.0 \mathrm{mgN} \cdot \mathrm{L}^{-1}$, RSD should exceed $11.31 \%$. Again, the results obtained meet the requirements established by MAPA (BRASIL, 2014) and by INMETRO (2011).

To verify the accuracy, the relative error was calculated for each of the levels studied, as described in the methodology. The percent errors were found to be 15.8 and $8.1 \%$ for the concentrations of 5.0 and $10.0 \mathrm{mgN} \cdot \mathrm{L}^{-1}$, respectively. Thus, it can be stated that the method under study is accurate, since the value of the relative error must be less than or equal to $20 \%$ (BRASIL, 2014).

The limits of detection (LOD) and quantification (LOQ) of the method were determined by analytical curve parameters. It was verified that LOD and LOQ, considering 7 replicates of the blank $(s=0.001817)$ and the coefficient of the analytical curve $(S=0.0107)$, presented values equal to $0.56 \mathrm{mgN} \cdot \mathrm{L}^{-1}$ and 1.70 $\mathrm{mgN} \cdot \mathrm{L}^{-1}$, respectively, and these values were adequate for the analyzes carried out by the laboratory where the method was implanted.

Finally, considering small variations of the parameters that are associated to the method, we chose to evaluate the reliability of the method based on the robustness test. Thus, from the new analytical curve $(y=0.0110 x+0.0016, r=0.99943)$ the mean concentration values and the contrasts of each factor were obtained, using Equation 12, which relates the mean concentration, $\mathrm{y}$, and the vector of the contractor coefficient matrix, $\mathrm{Xi}$, the results being presented in Table 4. 
$\mathrm{A}=\mathrm{Xi} \cdot \mathrm{y}$

Table 4 - Parameters of the new calibration curve, mean concentration, standard deviation and contractions of each factor in each test in the study of method robustness

\begin{tabular}{ccccccc}
\hline Essay & $\overline{\mathbf{C}}_{\mathbf{\pm} \mathbf{S}\left(\mathbf{m g N} \cdot \mathbf{L}^{-\mathbf{1}}\right)}$ & $\mathbf{A}$ & $\mathbf{B}$ & $\mathbf{C}$ & $\mathbf{D}$ & $\mathbf{E}$ \\
\hline $\mathbf{1}$ & $8.70 \pm 0.72$ & 8.70 & 8.70 & 8.70 & 8.70 & 8.70 \\
$\mathbf{2}$ & $8.80 \pm 0.19$ & 8.80 & 8.80 & -8.80 & -8.80 & -8.80 \\
$\mathbf{3}$ & $9.00 \pm 0.23$ & 9.00 & -9.00 & 9.00 & 9.00 & -9.00 \\
$\mathbf{4}$ & $8.20 \pm 1.27$ & 8.20 & -8.20 & -8.20 & -8.20 & 8.20 \\
$\mathbf{5}$ & $8.50 \pm 0.45$ & -8.50 & 8.50 & 8.50 & -8.50 & 8.50 \\
$\mathbf{6}$ & $7.60 \pm 0.56$ & -7.60 & 7.60 & -7.60 & 7.60 & -7.60 \\
$\mathbf{7}$ & $9.00 \pm 0.24$ & -9.00 & -9.00 & 9.00 & -9.00 & -9.00 \\
$\mathbf{8}$ & $9.10 \pm 0.05$ & -9.10 & -9.10 & -9.10 & 9.10 & 9.10 \\
\hline
\end{tabular}

To determine the effect of each factor, the result of the sum of the respective contrast values was divided by $2^{\mathrm{k}-1}$, where $\mathrm{k}$ corresponds to the number of factors. In order to evaluate if these effects are significant in the robustness, the standard deviation of the observations was calculated from the square root of the estimate of the joint experimental variance (Equation 13), which is obtained from the weighted average of all the estimates, using the values of the estimates of variance of all trials, and their respective degrees of freedom, $\mathrm{vi}$, as weights (Equation 14). Thus, the standard deviation obtained was equal to 0.59 .

$$
\begin{aligned}
& \mathrm{s}=\sqrt{\mathrm{s}^{2}} \\
& \mathrm{~s}^{2}=\frac{\sum_{\mathrm{i}=1}^{\mathrm{N}} \mathrm{v}_{\mathrm{i}} \mathrm{s}_{\mathrm{i}}^{2}}{\sum \mathrm{v}_{\mathrm{i}}}
\end{aligned}
$$

According to Barros Neto, Scarminio and Bruns (2010), the confidence interval of the standard deviation corresponds to $66.6 \%$ of the Gaussian curve. Therefore, to obtain the value of the acceptance criterion with a confidence limit of $95 \%$, the value of the Student $t$ distribution corresponding to 16 degrees of freedom (2.447) was multiplied by the standard deviation calculated (0.59), obtaining the value of the confidence limit equal to 1.25 (Table 5).

Table 5 - Effect and influence of each factor in the study of method robustness

\begin{tabular}{cccc}
\hline Factor & Efect & Acceptance criterion & Influence on results \\
\hline Salt (A) & 0.14 & & Not significant \\
$\mathrm{HCl}$ Volume (B) & -0.43 & & Not significant \\
$\mathrm{HCl}$ Concentration (C) & 0.37 & 1.25 & Not significant \\
$\mathrm{HCl}$ Brand (D) & -0.01 & & Not significant \\
Temperature (E) & 0.02 & & Not significant \\
\hline
\end{tabular}

Comparing the values of the effects obtained with the acceptance criterion, it was verified that no factor determined in this study has influence on the result. This finding can be made since the values of the obtained effects are below the criterion established to exert some type of interference. 


\subsection{Percentage recovery}

Based on the results obtained through Equation 6 (item 2.3), the collected drinking water samples can not be quantified in terms of the nitrate ion content, since the concentration values of this ion are lower than the LOD of the established method (Table 6).

Thus, the samples were fortified at a concentration of $10 \mathrm{mgN} \cdot \mathrm{L}^{-1}$, and the percentages of recovery were found to be adequate, since they meet the acceptance criterion determined by the MAPA, a recovery range of 80 to $110 \%$ for concentration values greater than or equal to $10 \mathrm{mgN} \cdot \mathrm{L}^{-1}$ (BRASIL, 2011a).

Table 6 - Percentage recovery study results in actual samples

\begin{tabular}{ccccc}
\hline & Sample & Abscor mean & C (mgN· $\left.\mathbf{L}^{-1}\right)$ & R (\%) \\
\hline \multirow{3}{*}{ Without fortification } & 1 & -0.0090 & $\mathrm{ND}$ & \\
& 2 & -0.0095 & $\mathrm{ND}$ & \\
& 3 & 0.0200 & $1,68^{*}$ & $\mathrm{NA}$ \\
& 4 & 0.0400 & $3.51^{*}$ & \\
With fortification & 5 & -0.0090 & $\mathrm{ND}$ & \\
& 6 & -0.0095 & $\mathrm{ND}$ & \\
& 1 & 0.1050 & 9.44 & 94.4 \\
& 2 & 0.1020 & 9.17 & 91.7 \\
& 3 & 0.1235 & 11.13 & 94.5 \\
& 4 & 0.1535 & 13.87 & 103.6 \\
& 5 & 0.0985 & 8.85 & 88.5 \\
& 6 & 0.1055 & 9.49 & 94.9 \\
\hline
\end{tabular}

$R(\%)=$ Percentage recovery. $N A=$ Non-applicable. $N D=$ Non-detectable. ${ }^{*}$ Not quantifiable

Therefore, the method evaluated met the requirements of the performance verification, as well as presents advantages over some methods described by APHA (2012), as the phenoldissulfonic acid method, which uses toxic reagents and requires several steps for the quantification of the nitrate ion, besides not being satisfactory in relation to the statistical evaluation presented by Mazon et al. (2005), and the reduction methods with hydrazine (BELGRANO; COLASURDO; DIAZ, 2003) and reduction with cadmium, also suggested by APHA (2012).

\section{CONCLUSION}

The method presented good performance, since all validation parameters studied met the criteria established by the literature, thus ensuring the reliability of the results. In addition, the use of equipment requiring a low sample volume $(\mu \mathrm{L})$ was satisfactory for the intended purpose, so that the spectrophotometric method proved to be advantageous for the determination of nitrate ion in water, when compared with other methods also used for the same purpose, since it presents a greater simplicity and low cost.

\section{ACKNOWLEDGMENT}

To the Laboratório Nacional Agropecuário de Pernambuco (LANAGRO-PE), belonging to the Ministério da Agricultura, Pecuária e Abastecimento (MAPA), and to the Agência de Defesa Agropecuária de Pernambuco (ADAGRO-PE). 


\section{REFERENCES}

AMERICAN PUBLIC HEALTH ASSOCIATION, AMERICAN WATER WORKS ASSOCIATION WATER, ENVIRONMENT FEDERATION. Standard Methods for the Examination of Water and Wastewater. 22th ed. Washington, DC: American Public Health Association, p. 122-128, 2012.

ANDRIOTTI, J. L. S. Técnicas estatísticas aplicáveis a tratamento de informações oriundas de procedimentos laboratoriais. Porto Alegre: CPRM, 2005, 41 p.

BARBIERI, E.; MARQUES, H. L. A.; BONDIOLI, A. C. V.; CAMPOLIM, M. B.; FERRARIN, A.T. Concentrações do nitrogênio amoniacal, nitrito e nitrato em áreas de engorda de ostras no município de Cananeia-SP. O Mundo da Saúde, v. 38, n. 1, p. 105-115, 2014.

BARROS NETO, B.; SCARMINIO, I. E.; BRUNS, R. E. Como fazer experimentos: aplicações na ciência e na indústria. 4. ed. Porto Alegre: Bookman, 2010. 414 p.

BEKA J.E; UDOM G.J. Quality status of groundwater in Akwa Ibom State, Nigeria. International Journal of Science Inventions Today, v. 3, n. 5, 2014.

BELGRANO, R. F.; COLASURDO V.; DÍAZ, O. A. Métodos ultravioleta selectivo y de reducción con hidracina en la determinación del Ión nitrato an aguas subterrâneas. Quimica Nova, v. 26, n. 5, p. 766768, 2003.

BRASIL. Agência Nacional de Vigilância Sanitária. Resolução RE no 899. Brasília: Diário Oficial da União, 2003.

BRASIL. Ministério da Agricultura, Pecuária e Abastecimento. Manual de Garantia da Qualidade Analítica - Resíduos e Contaminantes em Alimentos. Brasília: MAPA/ACS, 2011a, 227 p.

BRASIL. Ministério da Agricultura, Pecuária e Abastecimento. Manual de validação, verificação/confirmação de desempenho, estimativa da incerteza de medição e controle de qualidade intralaboratorial. Brasília: Coordenação Geral de Apoio Laboratorial (CGAL), 2014. 38 p.

BRASIL. Ministério da Saúde. Portaria nํ2914, de 12 de dezembro de 2011. Brasília: Diário Oficial da União, 2011b.

BUI, M. N., BROCKGREITENS, J.; AHMED, S. ABBAS, A. Dual detection of nitrate and mercury in water using disposable electrochemical sensors. Biosensors and Bioelectronics, v. 85, p. 280-286, 2016.

GUIMARÃES, V.; DURÃO, H.; AZENHA, M. Detailed Validation of a Method for the Determination of Nitrate in Water by UV/Vis Spectroscopy. Journal of AOAC International, 2014.

Instituto Nacional de Metrologia, Normalização e Qualidade Industrial (INMETRO). DOQ-CGCRE-008: Orientações sobre Validação de Métodos Analíticos. Rev. 04, 2011. 20 p.

JAIN, H. K.; PETHKAR, S. V. Development and validation of UV spectrophotometric method for analysis of nortryptaline hydrochloride in bulk and tablet dosage form. World Journal of Pharmacy and Pharmaceutical Sciences, v. 5, n. 7, p. 1452-1459, 2016. 
KHAN, M. F.; RITA, S. A.; KAYSER, MD. S.; ISLAM, MD. S.; ASAD, S.; RASHID, R. B.; BARI, MD. A.; RAHMAN, M. M.; AMAN, D. A. A. A.; SETU, N. I.; BANOO, R.; RASHID, M. A. Theoretically Guided Analytical Method Development and Validation for the Estimation of Rifampicin in a Mixture of Isoniazid and Pyrazinamide by UV Spectrophotometer. Frontiers in Chemistry, v. 5, n. 27, p. 1-12, 2017.

KREUTZ, D. H.; WEIZENMANNA, M.; MACIELA, M. J.; SOUZA, C. F. V. Avaliação das Concentrações de Nitrato e Nitrito em Hortaliças Produzidas em Cultivos Convencional e Orgânico na Região do Vale do Taquari - RS. UNOPAR Científica Ciências Biológicas e da Saúde, v. 14, n. 2, p. 05-10, 2012.

MAZON, E. M. A.; OLIVEIRA, A. C. G.; BRÍGIDO, B. M.; FREITAS, V. P. S. Estudo comparativo de métodos para determinação de nitrato em águas para consumo humano. Revista Instituto Adolfo Lutz, v. 64, n. 1, p. 110-116, 2005.

MENDONÇA, M. H. M.; ROSENO, S. A. M.; CACHOEIRA, T. R. L.; SILVA, Á. F. S.; JÁCOME, P. R. L. A.; JÁCOME JÚNIOR, A. T. Análise bacteriológica da água de consumo comercializada por caminhõespipa. Revista Ambiente e Água, v. 12, n. 3, p. 468-475, 2017.

MOO, Y.C.; MATJAFRI, M.Z., LIM, H.S., TAN, C.H. New development of optical fibre sensor for determination of nitrate and nitrite in water. Optik, v. 127, p. 1312-1319, 2016.

NAZ, S.; VALLEJO, M., GARCÍA, A.; BARBAS, C. Method validation strategies involved in nontargeted metabolomics. Journal of Chromatography A, v. 1353, p. 99-105, 2014.

SEN, A. K.; HINSU, D. N.; SEN, D. B.; ZANWAR, A. S.; MAHESHWARI, R. A., CHANDRAKAR, V. R. Analytical method development and validation for simultaneous estimation of Teneligliptin hydrobromide hydrate and Metformin hydrochloride from it's pharmaceutical dosage form by three different UV spectrophotometric methods. Journal of Applied Pharmaceutical Science, v. 6, n. 9, p. 157-165, 2016.

SILVA, J. A.; GUIMARÃES, G. P.; PATRIOTA, Y. B. G.; SILVA, N. E. S., SOUSA, C. E. M.; MENDONÇA JUNIOR, F. J. B.; SANTANA, D. P.; DAMASCENO, B. P. G. L. Desenvolvimento e validação de metodologias analíticas para quantificação de um derivado tiofênico em sistemas microemulsionados.

Revista de Ciências Farmacêuticas Básica e Aplicada, v. 35, n. 4, p. 643-649, 2014.

ZENEBON, O.; PASCUET, N. S.; TIGLEA, P. Métodos físico-químicos para análise de alimentos, São Paulo: Instituto Adolfo Lutz, 2008, 1020 p. 